medRxiv preprint doi: https://doi.org/10.1101/2021.04.14.21255472; this version posted April 14, 2021. The copyright holder for this preprint (which was not certified by peer review) is the author/funder, who has granted medRxiv a license to display the preprint in perpetuity.

All rights reserved. No reuse allowed without permission.

\title{
Circulating Plasma Biomarkers in Biopsy-Confirmed Kidney Disease: Results from the Boston Kidney Biopsy Cohort
}

Insa M. Schmidt, MD, MPH ${ }^{1,2}$; Suraj Sarvode Mothi, $\mathrm{MPH}^{2}$; Parker C. Wilson, MD, PhD ${ }^{3}$; Ragnar Palsson, $\mathrm{MD}^{4}$; Anand Srivastava, MD, MPH${ }^{5}$; Zoe A. Kibbelaar, BS ${ }^{1,2}$; Min Zhuo, $\mathrm{MD}^{2,6}$; Afolarin Amodu, MD, MPH ${ }^{1,2}$; Isaac E. Stillman, $\mathrm{MD}^{7}$; Helmut G. Rennke, $\mathrm{MD}^{8}$; Benjamin D. Humphreys, MD, $\mathrm{PhD}^{9}$; Sushrut S. Waikar, MD, MPH ${ }^{1,2}$

${ }^{1}$ Section of Nephrology, Department of Medicine, Boston University School of Medicine, Boston Medical Center, Boston, MA

${ }^{2}$ Renal Division, Brigham \& Women's Hospital, Boston, MA

${ }^{3}$ Department of Pathology and Immunology, Washington University, St. Louis, MO

${ }^{4}$ Division of Nephrology, Landspitali-The National University Hospital of Iceland, Faculty of

Medicine, School of Health Sciences, University of Iceland, Reykjavik, Iceland

${ }^{5}$ Division of Nephrology and Hypertension, Center for Translational Metabolism and Health,

Institute for Public Health and Medicine, Northwestern University Feinberg School of Medicine,

Chicago, IL

${ }^{6}$ Division of Nephrology, Beth Israel Deaconess Medical Center, Boston, MA

${ }^{7}$ Department of Pathology, Beth Israel Deaconess Medical Center, Boston, MA

${ }^{8}$ Department of Pathology, Brigham \& Women's Hospital, Boston, MA

${ }^{9}$ Division of Nephrology, Department of Medicine, Washington University, St. Louis, MO

Running title: Circulating plasma biomarkers in human kidney disease

Word count of abstract: 225

Word count of text: 3296

Tables: 2

Figures: 2

Key words: kidney disease, proteomics, kidney biopsy, histopathology

Corresponding author:

Sushrut S. Waikar, MD, MPH

Section of Nephrology, Department of Medicine

Boston University School of Medicine and Boston Medical Center

650 Albany Street, X504

Boston, MA 02118

Phone: (617) 638-3559

Email: swaikar@bu.edu 
medRxiv preprint doi: https://doi.org/10.1101/2021.04.14.21255472; this version posted April 14, 2021. The copyright holder for this preprint (which was not certified by peer review) is the author/funder, who has granted medRxiv a license to display the preprint in perpetuity.

\section{Abstract}

Background: Biomarkers for non-invasive assessment of histopathology and prognosis are needed in patients with kidney disease.

Methods: Using a proteomics assay, we measured a multi-marker panel of 225 circulating plasma proteins in a prospective cohort study of 549 individuals with biopsy-confirmed kidney diseases and semi-quantitative assessment of histopathology. We tested the associations of each biomarker with histopathologic lesions and the risks of kidney disease progression (defined as $\geq 40 \%$ decline in eGFR or ESKD) and death.

Results: After multivariable adjustment and correction for multiple testing, 46 proteins associated with different histopathologic lesions. The top performing markers positively associated with acute tubular injury and interstitial fibrosis and tubular atrophy were kidney injury molecule-1 (KIM-1) and V-set and immunoglobulin domain-containing protein 2 (VSIG2). 30 proteins were significantly associated with kidney disease progression and 35 with death. The top performing markers for kidney disease progression were placental growth factor (PGF; HR 5.4 , 95\% CI 3.4 to 8.7) and BMP and Activin Membrane Bound Inhibitor (BAMBI; HR 3.0, 95\% CI 2.1 to 4.2); the top performing markers for death were TRAIL-receptor-2 (TRAIL-R2; HR 2.9, 95\% CI 2.0 to 4.0) and CUB Domain Containing Protein-1 (CDCP1; HR $2.4,95 \%$ CI $1.8,3.3)$.

Conclusion: We identified several biomarkers associated with kidney disease histopathology and prognosis - many of which have not been reported previously and may represent important avenues for future research. 
medRxiv preprint doi: https://doi.org/10.1101/2021.04.14.21255472; this version posted April 14, 2021. The copyright holder for this preprint (which was not certified by peer review) is the author/funder, who has granted medRxiv a license to display the preprint in perpetuity.

\section{Introduction}

The two measures used to diagnose and stage kidney diseases, albuminuria and the estimated glomerular filtration rate (eGFR), do not provide specificity about kidney histopathological lesions and are imperfect prognostic markers. Novel biomarkers with greater specificity for histopathologic lesions will enhance clinical phenotyping of kidney diseases and may provide an important milestone toward precision medicine.

Several biomarkers of kidney inflammation and tubular injury have been shown to prognosticate the risk of adverse clinical outcomes in patients with kidney diseases, ${ }^{1-4}$ but these biomarkers only represent a small segment of the human blood proteome. Proteomics-based approaches add to this by allowing for an unbiased protein discovery that does not entirely depend on pre-existing pathophysiologic knowledge. The history of biomarker studies in other clinical disciplines illustrates how large-scale proteomics approaches can identify important protein markers for improved risk prediction ${ }^{5}$ and the development of new therapeutic targets. ${ }^{6}$ Fewer studies, however, have made use of these techniques for investigation of human kidney disease. $^{7-9}$

In this study, we used a novel proteomics assay to measure a multi-marker panel of 225 plasma proteins in a prospective cohort study of individuals with biopsy-confirmed kidney diseases and adjudicated semi-quantitative assessment of histopathology. We tested the associations of each biomarker with kidney histopathologic lesions and the risks of subsequent kidney disease progression and death, and explored pathways enriched in the plasma proteome of patients with kidney diseases using the Reactome pathway database. 


\section{Methods}

\section{Study Population}

The Boston Kidney Biopsy Cohort (BKBC) is a prospective, observational cohort study of patients undergoing native kidney biopsy at three tertiary care hospitals in Boston, Massachusetts, including Brigham and Women’s Hospital, Massachusetts General Hospital, and Beth Israel Deaconess Medical Center. Details of the study design have been previously described..$^{10}$ The study includes adults $\geq 18$ years of age who underwent a clinically indicated native kidney biopsy between September 2006 and October 2018. Exclusion criteria were the inability to provide written consent, severe anemia, pregnancy, and enrollment in competing studies. Patients provided blood and urine samples on the day of kidney biopsy. For this study, we evaluated 549 participants with available plasma samples that included both common and more rare forms of kidney diseases. The Partners Human Research Committee (the Brigham and Women's Hospital Institutional Review Board) approved the study protocol which is in accordance with the principles of the Declaration of Helsinki.

\section{Sample Collection, Proteomics Assays, and Exposures}

Blood samples were collected from study participants on the day of biopsy, aliquoted, and immediately stored at $-80^{\circ} \mathrm{C}$. Aliquots were analyzed at Olink using high-throughout, multiplex immunoassays ${ }^{11}$ on three commercially available panels named Inflammation, Organ Damage, and Cardiovascular II. Each panel consists of 92 biomarker proteins that were chosen based on their potential relevance in various pathological processes. All protein values are expressed as normalized protein expression (NPX) values on a $\log _{2}$ scale. We included $5 \%$ blind split replicates in addition to $\mathrm{BKBC}$ samples. Of the 276 proteins included in the three panels, we 
medRxiv preprint doi: https://doi.org/10.1101/2021.04.14.21255472; this version posted April 14, 2021. The copyright holder for this preprint (which was not certified by peer review) is the author/funder, who has granted medRxiv a license to display the preprint in perpetuity.

All rights reserved. No reuse allowed without permission.

used 225 biomarkers as the primary exposures for statistical analyses that were non-overlapping across the panels and passed the following quality control metrics: Coefficients of variation (CV) $<10 \%$ from blind split replicates; standard deviation (SD) of internal Olink controls $<0.2$, and incubation or detection control which deviated $<+/-0.3$ from the median value of all samples on the plate. As an additional quality control, we included multiple plasma aliquots from two patients, one with high and one with low eGFR, which were spread randomly in dummy labeled tubes across the shipment boxes. The mean CVs were $5.5(+/-4.3)$ and $4.9(+/-4.6)$, respectively, for the 225 biomarkers.

\section{Histopathologic Outcomes}

Kidney biopsy specimens were adjudicated under light microscopy by two experienced kidney pathologists who provided semiquantitative scores of kidney inflammation, fibrosis, vascular sclerosis, and acute tubular injury (Supplemental Table 1). Methods to evaluate and score histopathologic lesions were previously described in detail. ${ }^{10}$ Of the 13 histopathologic lesions adjudicated, all were scored during study sessions except for grades of global or segmental glomerulosclerosis, which were taken from the biopsy report, because they were each calculated as a percentage of the total number of glomeruli. We combined endocapillary glomerular inflammation, extracapillary cellular crescents, focal glomerular necrosis, and fibrocellular crescents into a single dichotomous variable named 'glomerular inflammation' due to the relatively low prevalence and limited range of severity for each of those lesions in this cohort. All participants' charts were reviewed alongside histopathologic evaluations to provide the final primary clinicopathologic diagnosis. 
medRxiv preprint doi: https://doi.org/10.1101/2021.04.14.21255472; this version posted April 14, 2021. The copyright holder for this preprint (which was not certified by peer review) is the author/funder, who has granted medRxiv a license to display the preprint in perpetuity.

All rights reserved. No reuse allowed without permission.

\section{Clinical Outcomes}

The primary outcome was kidney disease progression, defined as $\geq 40 \%$ decline in eGFR or ESKD (initiation of dialysis or kidney transplantation). The secondary outcome was death. Data on eGFR during follow-up was obtained from the electronic medical record (EMR) and ESKD status was confirmed by reviewing the EMR and linkage with the US Renal Data System database. Mortality status was confirmed with the Social Security Death Index. Participants were followed until the occurrence of death, voluntary study withdrawal, loss to follow-up, or February 1, 2020.

\section{Covariates}

Detailed patient information was collected at the biopsy visit, including demographics, medical history, medication lists, and pertinent laboratory data and stored using REDCap electronic data capture tools hosted at Partners Health Care. We obtained serum creatinine (SCr) from the EMR on the day of biopsy. In participants for whom this was unavailable, we measured SCr in available blood samples collected on the day of biopsy. We obtained spot urine proteinto-creatinine ratio or urine albumin-to-creatinine ratio from the date of kidney biopsy up to 3 months before biopsy from the EMR. SCr and urine creatinine were measured using a Jaffebased method and urine albumin was measured by an immunoturbidometric method. The creatinine-based Chronic Kidney Disease Epidemiology Collaboration equation was used to calculate the eGFR. $^{12}$

\section{Pathway Analyses}


medRxiv preprint doi: https://doi.org/10.1101/2021.04.14.21255472; this version posted April 14, 2021. The copyright holder for this preprint (which was not certified by peer review) is the author/funder, who has granted medRxiv a license to display the preprint in perpetuity.

All rights reserved. No reuse allowed without permission.

Pathway analyses were performed using Reactome. ${ }^{13}$ Reactome employs the BenjaminiHochberg approach to provide a False Discovery Rate (FDR) that accounts for the number of tests performed. Statistical significance was assessed by permuting group labels using 1,000 permutations and pathways were ranked according to their p-values and FDR.

\section{Statistical Analysis}

We summarized descriptive statistics as count with percentages for categorical variables and mean \pm standard deviation or median with interquartile range for continuous variables. For skewed data distributions, we performed natural logarithmic transformation as appropriate. Unadjusted and adjusted multivariable linear regression models were used to assess associations of each plasma biomarker protein with histopathologic lesions. For these analyses, histopathologic lesions were dichotomized as less severe versus more severe lesions. We limited statistical analyses on histopathologic lesions to participants with adjudicated histopathology by both kidney pathologists $(n=411,75 \%)$ except for analyses of global or segmental glomerulosclerosis since they were taken from the biopsy report $(n=549)$.

We performed time-to-event analyses to examine the associations of biomarkers with kidney disease progression and death. Cox proportional hazard models were stratified by site and adjusted for age, race, sex, $\log$ (proteinuria), eGFR, and primary clinicopathologic diagnostic category of kidney disease. For the outcome of kidney disease progression, we treated the data as interval censored because the exact date of the event may not be known. We evaluated the association between plasma biomarkers and subsequent kidney disease progression using a nonparametric survival function for interval-censored data. ${ }^{14}$ We confirmed no violations of the proportional hazards assumption through assessment of Schoenfeld residuals and used complete 
medRxiv preprint doi: https://doi.org/10.1101/2021.04.14.21255472; this version posted April 14, 2021. The copyright holder for this preprint (which was not certified by peer review) is the author/funder, who has granted medRxiv a license to display the preprint in perpetuity.

All rights reserved. No reuse allowed without permission.

case analysis for the analyses as there were less than 5\% missing data. To counteract the problem of multiple testing, we used Bonferroni correction (adjusted $\mathrm{p}$-value $=\mathrm{k} \times \mathrm{p}_{\text {naive }}$, where $\mathrm{k}$ is the number of biomarkers included in the analyses $(n=225)$ and $\left.\mathrm{p}_{\text {naive }}=0.05\right)$ for all reported $\mathrm{p}$-values. Statistical analyses were performed using R Version 3.6.1 (R Foundation for Statistical Computing, Vienna, Austria).

\section{Results}

\section{Baseline Characteristics}

Baseline characteristics of the study cohort are shown in Table 1. The mean age was $51.6 \pm 16.7$ years and $52.5 \%$ were women. The mean eGFR was $57.8 \pm 36.4 \mathrm{ml} / \mathrm{min} / 1.73 \mathrm{~m}^{2}$ and the median proteinuria (IQR) was $1.7(0.4,3.8) \mathrm{g} / \mathrm{g}$ creatinine. The most common primary clinicopathologic diagnoses were glomerulopathies (47.0\%), diabetic nephropathy (11.7\%), advanced glomerulosclerosis $(11.3 \%)$, vascular disease $(9.5 \%)$, and tubulointerstitial disease $(8.6 \%)$

Plasma protein biomarkers associated with histopathologic lesions

Associations between plasma biomarkers and histopathologic lesions are shown in Figure 1 and Supplemental Table 2. After multivariable adjustment and correction for multiple testing, 46 plasma proteins were independently associated with different histopathologic lesions. By level of statistical significance, the top-performing biomarkers positively associated with more severe acute tubular injury (ATI) and interstitial fibrosis/tubular atrophy (IFTA) were kidney injury molecule-1 (KIM-1) and V-set and immunoglobulin domain-containing protein 2 (VSIG2), respectively (Supplemental Table 2). The top-performing biomarkers positively 
medRxiv preprint doi: https://doi.org/10.1101/2021.04.14.21255472; this version posted April 14, 2021. The copyright holder for this preprint (which was not certified by peer review) is the author/funder, who has granted medRxiv a license to display the preprint in perpetuity.

All rights reserved. No reuse allowed without permission.

associated with other lesions included: Protein S100-A12 (EN-RAGE) with greater severity of glomerular inflammation; C-X-C motif chemokine 9 (CXCL9) with inflammation in the nonfibrosed interstitium; tissue factor (TF) with glomerular sclerosis, and tumor necrosis factor (TNF)-related apoptosis-inducing ligand (TRAIL) with mesangial expansion. Matrix metalloproteinase-7 (MMP-7) and fatty acid-binding protein 2 (FABP-2) were the top performing markers associated with more severe inflammation in the fibrosed interstitium and arteriolar sclerosis, respectively. Nine biomarkers were inversely associated with histopathologic lesions (Supplemental Table 2). Among those, stem cell factor (SCF) associated inversely with both acute tubular injury and inflammation in the non-fibrosed interstitium. There was no significant association between any of the biomarkers and segmental glomerulosclerosis or arterial sclerosis after multivariable adjustment.

\section{Plasma protein biomarkers associated with kidney disease progression}

170 individuals suffered kidney disease progression during a median follow-up of 51.8 months. Higher levels of 30 plasma proteins were independently associated with greater risk of kidney disease progression (Figure 2A and Supplemental Table 3). In multivariable-adjusted models, higher levels of the following biomarkers were associated with greater risks of kidney disease progression (top 5 findings in the order of level of significance): Placental growth factor (PGF), BMP and activin membrane bound inhibitor (BAMBI), TNF-receptor superfamily-11A (TNFRSF-11A), TNF-related apoptosis-inducing ligand-R2 (TRAIL-R2/TNFRSF-10B), and CX3-C motif chemokine ligand 1 (CX3CL1). Among all 30 proteins, several were interleukins (IL) and IL-receptors (IL-4RA, IL-10RB, IL-15RA, IL-16), hemostatic markers (thrombomodulin (TM), protease-activated receptor-1 (PAR-1), TF) and members of the TNF- 
medRxiv preprint doi: https://doi.org/10.1101/2021.04.14.21255472; this version posted April 14, 2021. The copyright holder for this preprint (which was not certified by peer review) is the author/funder, who has granted medRxiv a license to display the preprint in perpetuity.

All rights reserved. No reuse allowed without permission.

superfamily (TNFRSF-9, TNFRSF-10A, TRAIL-R2/TNFRSF-10B, TNFRSF-11A). Cytokine signaling and activation of the clotting cascade were among the top ranked pathways associated with kidney disease progression (Table 2).

Plasma protein biomarkers associated with death

82 participants died during a median follow-up of 59.4 months, respectively. Higher levels of 30 proteins and lower levels of 5 proteins were independently associated with greater risk of death (Figure 2B and Supplemental Table 4). The top 5 proteins positively associated with greater risk of death according to level of significance were TRAIL-R2/TNFRSF-10B, CUB domain containing protein 1 (CDCP1), TNFRSF10A, programmed death-ligand 1 (PDL1/CD274), and brain natriuretic peptide (BNP). The 5 plasma proteins inversely associated with greater risk of death were SCF, Desmoglein-4 (DSG4), Carbonic anhydrase 14 (CA14), Plexin domain-containing protein 1 (PLXDC1), and disintegrin and metalloproteinase with thrombospondin motifs-13 (ADAMTS13). Among all proteins associated with death, there were several members of the TNF-superfamily (TNFRSF-9, TNFRSF-10A, TNFRSF-10B/TRAIL-R2, TNFRSF-11A) as well as cytokines and cytokine receptors involved in Th2 inflammation (IL4RA, IL-6), NK cell regulation (IL18R1, IL15RA, IL27) and neutrophil recruitment (CXCL8/IL8). Cytokine and interleukin signaling pathways were among the top ranked pathways associated with death (Table 2).

\section{Discussion}

This study provides an assessment of the plasma proteome in a cohort of individuals with biopsy-confirmed kidney diseases. We evaluated associations of 225 plasma biomarkers with 
medRxiv preprint doi: https://doi.org/10.1101/2021.04.14.21255472; this version posted April 14, 2021. The copyright holder for this preprint (which was not certified by peer review) is the author/funder, who has granted medRxiv a license to display the preprint in perpetuity.

All rights reserved. No reuse allowed without permission.

histopathologic findings in native kidney biopsies and subsequent risks of kidney disease progression and death and identified several new promising biomarker candidates. Pathways enriched in the plasma proteome of patients with kidney diseases point toward key mechanisms involved in disease pathogenesis, including inflammation, extracellular matrix remodeling, disturbances of hemostasis, cell growth, and apoptosis.

Previous large-scale proteomics studies have primarily focused on evaluation of the urine CKD proteome. ${ }^{15-19}$ Fewer studies have utilized proteomics to interrogate plasma in patients with CKD. ${ }^{9,20-22}$ Some of the individual proteins that we investigated have previously been shown to be associated with histopathologic lesions and adverse clinical outcomes in individuals with kidney disease. Among those are plasma KIM-1 ${ }^{1,23}$ and fibroblast growth factor-23 (FGF-23). ${ }^{4}$ Many others are new findings that represent areas for future investigation.

\section{Biomarkers of Histopathology}

In line with results from previous studies, KIM-1 was the biomarker most strongly associated with more severe ATI. ${ }^{1,2}{ }^{23}$ VSIG2, a protein of unknown function, was the topperforming marker for IFTA. VSIG2 has been associated with incident heart failure ${ }^{24}$ and prevalent diabetes in the general population, ${ }^{25}$ but there are no studies, to our knowledge, that have linked VSIG2 to kidney diseases. Several inflammatory markers were associated with histopathologic lesions. EN-RAGE, a pro-inflammatory marker which leads to IL-1 $\beta$ and TNF- $\alpha$ release, had the strongest association with glomerular inflammation. In rodent models of CKD, EN-RAGE was reported to play a key role in the pathogenesis of vascular calcification through modulation of Pi co-transporter (Pit-1) expression. ${ }^{26}$ This finding is supported by previous studies in humans that described associations between elevated plasma EN-RAGE levels and 
atherosclerosis as well as cardiovascular and all-cause mortality in patients on dialysis. ${ }^{27-29}$ Our study adds that EN-RAGE may be crucial not only for sustaining chronic systemic inflammation in individuals with kidney disease but may also be an important marker specific for glomerular inflammation. The single marker that remained significantly associated with vascular pathology after multivariable adjustment was FABP2, a protein expressed in epithelial cells of the small intestines and involved in the reabsorption and distribution of long-chain fatty acids. ${ }^{30}$ Polymorphisms in the FABP2 gene have been linked to insulin resistance, dyslipidemia, and cardiovascular diseases. ${ }^{30,31} \mathrm{We}$ are not aware of any prior studies that have evaluated plasma FABP2 in kidney disease.

\section{Biomarkers of Adverse Clinical Events}

A previous plasma proteomics study by Carlsson et al. of individuals from the general population identified 20 plasma proteins that were associated with incident CKD. ${ }^{20}$ Although the associations in the Carlsson study lost statistical significance after adjustment for baseline eGFR, seven of these proteins (TRAIL-R2, PGF, CD40, PAR-1, FGF-23, CSF-1, and TM) were also associated with kidney disease progression in our study and remained statistically significant after multivariable adjustment. We observed a particularly strong association for PGF, a member of the vascular endothelial growth factor (VEGF) family that has previously been studied in the setting of preeclampsia where lower circulating maternal PGF levels were found to be associated with the disease. ${ }^{32,33}$ A prior study in kidney disease demonstrated that higher PGF levels associated with lower risks of AKI and mortality in patients undergoing cardiac surgery, ${ }^{34}$ but another study identified that higher PGF levels associated with an increased risk of incident CKD. ${ }^{20}$ We observed an increased risk of kidney disease progression with higher PGF levels. It 
medRxiv preprint doi: https://doi.org/10.1101/2021.04.14.21255472; this version posted April 14, 2021. The copyright holder for this preprint (which was not certified by peer review) is the author/funder, who has granted medRxiv a license to display the preprint in perpetuity.

All rights reserved. No reuse allowed without permission.

is possible that in patients with established CKD, PGF levels may not have a pathogenic role but rather reflect a compensatory response to sustained angiogenic imbalance that is present in the setting of chronic injury. We also observed a strong association between higher levels of BAMBI and greater risk of kidney disease progression. BAMBI serves as a regulator of angiogenesis and endothelial homeostasis through modulation of alternative TGF- $\beta$ signaling pathways such as extracellular signal-related kinase (ERK)1/2 and Smad1/5. ${ }^{35,36}$ Diabetic $\mathrm{BAMBI}^{-/-}$mice develop more severe albuminuria with increased activation of alternative TGF- $\beta$ pathways compared to wildtype animals. ${ }^{35}$ In this study, we observed an association between higher, not lower, BAMBI levels and greater risks of kidney disease progression. Since our cohort primarily included patients with established CKD, these findings may point toward an important role of BAMBI in regulating anti-fibrotic responses while its elevation could be due to the active and ongoing fibrotic processes in CKD. This, however, remains to be tested in additional cohort studies of CKD.

The top-performing biomarker associated with increased risks of death was TRAIL-R2, a key mediator of apoptosis, which was also associated with kidney disease progression. TRAIL$\mathrm{R} 2$ is a death domain-containing receptor that is capable of transmitting apoptotic signals in response to TRAIL binding. ${ }^{37}$ TRAIL, a member of the TNF gene superfamily, has been shown to associate with albuminuria in diabetes and plays an important role in the progression of diabetic nephropathy by inducing renal cell death. ${ }^{20,37}$

We found lower levels of 5 plasma proteins to be associated with an increased risk of death. Among those was SCF, a regulator of bone marrow-derived stem cell migration and survival, known to act on early hematopoietic stem cells and primitive hematopoietic progenitor 
medRxiv preprint doi: https://doi.org/10.1101/2021.04.14.21255472; this version posted April 14, 2021. The copyright holder for this preprint (which was not certified by peer review) is the author/funder, who has granted medRxiv a license to display the preprint in perpetuity.

All rights reserved. No reuse allowed without permission.

cells. Findings from rodent models suggest that SCF is crucial to mediate tubular epithelial cell survival after hypoxic injury. ${ }^{38}$ Similar findings were reported in mice in which local injection of SCF improved cardiac function after myocardial infarction. ${ }^{39}$ In the Malmo Diet and Cancer Study, lower circulating levels of SCF associated with significantly higher risks of stroke and heart failure as well as cardiovascular and all-cause mortality. ${ }^{40}$ We observed similar findings in the current study and found lower SCF levels to be associated with an increased risk of death in patients with kidney diseases. Evaluation of inflammatory parameters in the Malmoe Diet and Cancer Study also revealed that C-reactive protein levels and white blood cell counts correlated inversely with SCF. ${ }^{40}$ In line with this, we showed that SCF was inversely associated with both ATI and interstitial inflammation which could suggest that SCF may attenuate inflammation in patients with kidney disease or that in turn inflammation may function as a negative regulator of SCF. We also found that lower levels of ADAMTS13 were associated with a greater risk of death. ADAMTS13 is a von Willebrand factor (VWF) cleaving protease, and deficiency of plasma ADAMTS13 activity causes thrombotic thrombocytopenic purpura. In a case-control study of patients with malignant hypertension, ADAMTS13 levels correlated inversely with creatinine and were significantly decreased in patients with more severe thrombotic microangiopathy and hypertension. ${ }^{41}$ While the functional relevance and putative prognostic value of these proteins need to be further explored, several biomarkers shared common biologic pathways with pathophysiological relevance for kidney diseases, including inflammation and extracellular matrix remodeling, apoptosis, angiogenesis, and endothelial dysfunction.

\section{Strengths and Limitations}


medRxiv preprint doi: https://doi.org/10.1101/2021.04.14.21255472; this version posted April 14, 2021. The copyright holder for this preprint (which was not certified by peer review) is the author/funder, who has granted medRxiv a license to display the preprint in perpetuity.

All rights reserved. No reuse allowed without permission.

Significant strengths of our study include the large number of protein biomarkers included in the analyses. Adjudicated histopathologic scores on lesion severity and the prospective study design with long-term follow up data allowed us to test associations not only with histopathology but also with major adverse clinical events including kidney disease progression and death. Our study has several limitations that warrant consideration as well. First, our approach was exploratory, and we cannot determine causality. We were not able to take serum creatinine values prior to biopsy into account and did not account for therapy at baseline which could alter levels of biomarkers or an individual's risk of disease progression or death. We were also not able to compare plasma protein measurements to protein measurements in the urine. Limitations of the proteomics assay include that protein values are obtained in relative quantification units (normalized protein expression values) rather than as absolute values which may limit comparability between studies. As we carefully selected 3 Olink proteomics panels based on their potential relevance for kidney disease, the selection of proteins included in the study limited our ability to perform unbiased pathway analyses.

In summary, we identified a number of protein biomarkers associated with histopathologic lesions on native kidney biopsy specimens and subsequent kidney disease progression and death. Several of our biomarker findings merit development of quantitative assays for further replication in other prospective cohort studies to develop markers for noninvasive diagnosis and optimal prognosis. Studies using techniques such as Mendelian randomization may identify which of our biomarker findings represent therapeutic targets for patients with specific kidney diseases. Our study demonstrates how findings from a cohort of individuals with available kidney pathology and prospective clinical follow-up can uncover 
medRxiv preprint doi: https://doi.org/10.1101/2021.04.14.21255472; this version posted April 14, 2021. The copyright holder for this preprint (which was not certified by peer review) is the author/funder, who has granted medRxiv a license to display the preprint in perpetuity.

All rights reserved. No reuse allowed without permission.

relevant pathways and biomarker candidates for understanding, diagnosing, and providing prognosis of kidney diseases. 
medRxiv preprint doi: https://doi.org/10.1101/2021.04.14.21255472; this version posted April 14, 2021. The copyright holder for this preprint (which was not certified by peer review) is the author/funder, who has granted medRxiv a license to display the preprint in perpetuity.

\section{Disclosures}

S.S.W. reports personal fees from Public Health Advocacy Institute, CVS, Roth Capital Partners, Kantum Pharma, Mallinckrodt, Wolters Kluewer, GE Health Care, GSK, Mass Medical International, Barron and Budd (vs. Fresenius), JNJ, Venbio, Strataca, Takeda, Cerus, Pfizer, Bunch and James, Harvard Clinical Research Institute (aka Baim), and grants and personal fees from Allena Pharmaceuticals. A.S. reports personal fees from Horizon Pharma, PLC, AstraZeneca, CVS Caremark, and medicolegal consulting (Tate \& Latham).

\section{Funding}

This study was supported by National Institutes of Health (NIH) grant R01DK093574 (S.S.W.).

\section{Acknowledgements}

We thank the members of the laboratory of S.S.W. for their invaluable assistance in the Boston

Kidney Biopsy Cohort. I.M.S. is supported by the American Philosophical Society Daland

Fellowship in Clinical Investigation. S.S.W. is also supported by NIH grants UH3DK114915, U01DK085660, U01DK104308, R01DK103784, and R21DK119751. A.S. is supported by NIH grant K23DK120811, NIDDK Kidney Precision Medicine Project Opportunity Pool grant under U2CDK114886, and core resources from the George M. O'Brien Kidney Research Center at Northwestern University (NU-GoKIDNEY) P30DK114857. M.Z. is supported by a NIH NIDDK T32 award DK007199. This work was conducted with support from Harvard Catalyst. The Harvard Clinical and Translational Science Center (National Center for Advancing Translational Sciences, National Institutes of Health Award UL1TR001102) and financial contributions from Harvard University and its affiliated academic healthcare centers. The content is solely the 
medRxiv preprint doi: https://doi.org/10.1101/2021.04.14.21255472; this version posted April 14, 2021. The copyright holder for this preprint

(which was not certified by peer review) is the author/funder, who has granted medRxiv a license to display the preprint in perpetuity.

All rights reserved. No reuse allowed without permission.

responsibility of the authors and does not necessarily represent the official views of Harvard

Catalyst, Harvard University and its affiliated academic healthcare centers, or the NIH.

Part of this work was presented as an oral presentation at the 2020 American Society of

Nephrology Scientific Session on October $22^{\text {th }}$.

\section{Author Contributions}

I.M.S, S.S.M, R.P., A.S., P.C.W., B.D.H., and S.S.W were responsible for the concept and design of the study. Z.A.K., A.A., M.Z., A.S., R.P. and S.S.W. adjudicated clinical outcomes. I.E.S. and H.G.R. were responsible for the adjudication of histopathology. S.S.M, I.M.S., and S.S.W. were responsible for statistical analyses. All authors interpreted the data. I.M.S. and S.S.W. drafted the manuscript. All authors contributed to critical revisions of the manuscript for important intellectual content. 
medRxiv preprint doi: https://doi.org/10.1101/2021.04.14.21255472; this version posted April 14, 2021. The copyright holder for this preprint (which was not certified by peer review) is the author/funder, who has granted medRxiv a license to display the preprint in perpetuity.

\section{References}

1. Sabbisetti VS, Waikar SS, Antoine DJ, Smiles A, Wang C, Ravisankar A, Ito K, Sharma S, Ramadesikan S, Lee M, Briskin R, De Jager PL, Ngo TT, Radlinski M, Dear JW, Park $\mathrm{KB}$, Betensky R, Krolewski AS, Bonventre JV: Blood kidney injury molecule-1 is a biomarker of acute and chronic kidney injury and predicts progression to ESRD in type I diabetes. J Am Soc Nephrol, 25: 2177-2186, 2014

2. Waikar SS, Sabbisetti V, Arnlov J, Carlsson AC, Coresh J, Feldman HI, Foster MC, Fufaa GD, Helmersson-Karlqvist J, Hsu CY, Kimmel PL, Larsson A, Liu Y, Lind L, Liu KD, Mifflin TE, Nelson RG, Riserus U, Vasan RS, Xie D, Zhang X, Bonventre JV: Relationship of proximal tubular injury to chronic kidney disease as assessed by urinary kidney injury molecule-1 in five cohort studies. Nephrol Dial Transplant, 31: 1460-1470, 2016

3. Niewczas MA, Pavkov ME, Skupien J, Smiles A, Md Dom ZI, Wilson JM, Park J, Nair V, Schlafly A, Saulnier PJ, Satake E, Simeone CA, Shah H, Qiu C, Looker HC, Fiorina P, Ware CF, Sun JK, Doria A, Kretzler M, Susztak K, Duffin KL, Nelson RG, Krolewski AS: A signature of circulating inflammatory proteins and development of end-stage renal disease in diabetes. Nat Med, 25: 805-813, 2019

4. Isakova T: Fibroblast growth factor 23 and adverse clinical outcomes in chronic kidney disease. Curr Opin Nephrol Hypertens, 21: 334-340, 2012

5. Ganz P, Heidecker B, Hveem K, Jonasson C, Kato S, Segal MR, Sterling DG, Williams SA: Development and Validation of a Protein-Based Risk Score for Cardiovascular Outcomes Among Patients With Stable Coronary Heart Disease. Jama, 315: 2532-2541, 2016

6. Loffredo FS, Steinhauser ML, Jay SM, Gannon J, Pancoast JR, Yalamanchi P, Sinha M, Dall'Osso C, Khong D, Shadrach JL, Miller CM, Singer BS, Stewart A, Psychogios N, Gerszten RE, Hartigan AJ, Kim MJ, Serwold T, Wagers AJ, Lee RT: Growth differentiation factor 11 is a circulating factor that reverses age-related cardiac hypertrophy. Cell, 153: 828-839, 2013

7. Bonomini M, Sirolli V, Pieroni L, Felaco P, Amoroso L, Urbani A: Proteomic Investigations into Hemodialysis Therapy. Int J Mol Sci, 16: 29508-29521, 2015

8. Tsalik EL, Willig LK, Rice BJ, van Velkinburgh JC, Mohney RP, McDunn JE, Dinwiddie DL, Miller NA, Mayer ES, Glickman SW, Jaehne AK, Glew RH, Sopori ML, Otero RM, Harrod KS, Cairns CB, Fowler VG, Rivers EP, Woods CW, Kingsmore SF, Langley RJ: Renal systems biology of patients with systemic inflammatory response syndrome. Kidney Int, 88: 804-814, 2015

9. Feldreich T, Nowak C, Fall T, Carlsson AC, Carrero JJ, Ripsweden J, Qureshi AR, Heimburger O, Barany P, Stenvinkel P, Vuilleumier N, Kalra PA, Green D, Arnlov J: Circulating proteins as predictors of cardiovascular mortality in end-stage renal disease. $J$ Nephrol, 32: 111-119, 2019

10. Srivastava A, Palsson R, Kaze A, Chen M, Palacios P, Sabbisetti V, Betensky R, Steinman T, Thadhani R, McMahon G, Stillman I, Rennke H, Waikar S: The Prognostic Value of Histopathologic Lesions in Native Kidney Biopsy Specimens: Results from the Boston Kidney Biopsy Cohort Study. J Am Soc Nephrol, 29: 2213-2224, 2018

11. Assarsson E, Lundberg M, Holmquist G, Björkesten J, Thorsen SB, Ekman D, Eriksson A, Rennel Dickens E, Ohlsson S, Edfeldt G, Andersson AC, Lindstedt P, Stenvang J, 
medRxiv preprint doi: https://doi.org/10.1101/2021.04.14.21255472; this version posted April 14, 2021. The copyright holder for this preprint (which was not certified by peer review) is the author/funder, who has granted medRxiv a license to display the preprint in perpetuity.

All rights reserved. No reuse allowed without permission.

Gullberg M, Fredriksson S: Homogenous 96-plex PEA immunoassay exhibiting high sensitivity, specificity, and excellent scalability. PLoS One, 9: e95192, 2014

12. Levey AS, Stevens LA, Schmid CH, Zhang YL, Castro AF, 3rd, Feldman HI, Kusek JW, Eggers P, Van Lente F, Greene T, Coresh J: A new equation to estimate glomerular filtration rate. Ann Intern Med, 150: 604-612, 2009

13. Jassal B, Matthews L, Viteri G, Gong C, Lorente P, Fabregat A, Sidiropoulos K, Cook J, Gillespie M, Haw R, Loney F, May B, Milacic M, Rothfels K, Sevilla C, Shamovsky V, Shorser S, Varusai T, Weiser J, Wu G, Stein L, Hermjakob H, D'Eustachio P: The reactome pathway knowledgebase. Nucleic Acids Res, 48: D498-d503, 2020

14. Zhang Z, Sun J: Interval censoring. Stat Methods Med Res, 19: 53-70, 2010

15. Lindhardt M, Persson F, Zurbig P, Stalmach A, Mischak H, de Zeeuw D, Lambers Heerspink H, Klein R, Orchard T, Porta M, Fuller J, Bilous R, Chaturvedi N, Parving HH, Rossing P: Urinary proteomics predict onset of microalbuminuria in normoalbuminuric type 2 diabetic patients, a sub-study of the DIRECT-Protect 2 study. Nephrol Dial Transplant, 32: 1866-1873, 2017

16. Good DM, Zurbig P, Argiles A, Bauer HW, Behrens G, Coon JJ, Dakna M, Decramer S, Delles C, Dominiczak AF, Ehrich JH, Eitner F, Fliser D, Frommberger M, Ganser A, Girolami MA, Golovko I, Gwinner W, Haubitz M, Herget-Rosenthal S, Jankowski J, Jahn H, Jerums G, Julian BA, Kellmann M, Kliem V, Kolch W, Krolewski AS, Luppi M, Massy Z, Melter M, Neususs C, Novak J, Peter K, Rossing K, Rupprecht H, Schanstra JP, Schiffer E, Stolzenburg JU, Tarnow L, Theodorescu D, Thongboonkerd V, Vanholder R, Weissinger EM, Mischak H, Schmitt-Kopplin P: Naturally occurring human urinary peptides for use in diagnosis of chronic kidney disease. Mol Cell Proteomics, 9: 24242437, 2010

17. Schanstra JP, Zurbig P, Alkhalaf A, Argiles A, Bakker SJ, Beige J, Bilo HJ, Chatzikyrkou C, Dakna M, Dawson J, Delles C, Haller H, Haubitz M, Husi H, Jankowski J, Jerums G, Kleefstra N, Kuznetsova T, Maahs DM, Menne J, Mullen W, Ortiz A, Persson F, Rossing P, Ruggenenti P, Rychlik I, Serra AL, Siwy J, Snell-Bergeon J, Spasovski G, Staessen JA, Vlahou A, Mischak H, Vanholder R: Diagnosis and Prediction of CKD Progression by Assessment of Urinary Peptides. J Am Soc Nephrol, 26: 1999-2010, 2015

18. Tofte N, Lindhardt M, Adamova K, Bakker SJL, Beige J, Beulens JWJ, Birkenfeld AL, Currie G, Delles C, Dimos I, Francova L, Frimodt-Moller M, Girman P, Goke R, Havrdova T, Heerspink HJL, Kooy A, Laverman GD, Mischak H, Navis G, Nijpels G, Noutsou M, Ortiz A, Parvanova A, Persson F, Petrie JR, Ruggenenti PL, Rutters F, Rychlik I, Siwy J, Spasovski G, Speeckaert M, Trillini M, Zurbig P, von der Leyen H, Rossing P: Early detection of diabetic kidney disease by urinary proteomics and subsequent intervention with spironolactone to delay progression (PRIORITY): a prospective observational study and embedded randomised placebo-controlled trial. Lancet Diabetes Endocrinol, 8: 301-312, 2020

19. Critselis E, Lambers Heerspink H: Utility of the CKD273 peptide classifier in predicting chronic kidney disease progression. Nephrol Dial Transplant, 31: 249-254, 2016

20. Carlsson AC, Ingelsson E, Sundstrom J, Carrero JJ, Gustafsson S, Feldreich T, Stenemo M, Larsson A, Lind L, Arnlov J: Use of Proteomics To Investigate Kidney Function Decline over 5 Years. Clin J Am Soc Nephrol, 12: 1226-1235, 2017

21. Glorieux G, Mullen W, Duranton F, Filip S, Gayrard N, Husi H, Schepers E, Neirynck N, Schanstra JP, Jankowski J, Mischak H, Argiles A, Vanholder R, Vlahou A, Klein J: New 
medRxiv preprint doi: https://doi.org/10.1101/2021.04.14.21255472; this version posted April 14, 2021. The copyright holder for this preprint (which was not certified by peer review) is the author/funder, who has granted medRxiv a license to display the preprint in perpetuity.

All rights reserved. No reuse allowed without permission.

insights in molecular mechanisms involved in chronic kidney disease using highresolution plasma proteome analysis. Nephrol Dial Transplant, 30: 1842-1852, 2015

22. Kammer M, Heinzel A, Willency JA, Duffin KL, Mayer G, Simons K, Gerl MJ, Klose C, Heinze G, Reindl-Schwaighofer R, Hu K, Perco P, Eder S, Rosivall L, Mark PB, Ju W, Kretzler M, McCarthy MI, Heerspink HL, Wiecek A, Gomez MF, Oberbauer R: Integrative analysis of prognostic biomarkers derived from multiomics panels helps discrimination of chronic kidney disease trajectories in people with type 2 diabetes. Kidney Int, 96: 1381-1388, 2019

23. Nowak N, Skupien J, Niewczas MA, Yamanouchi M, Major M, Croall S, Smiles A, Warram JH, Bonventre JV, Krolewski AS: Increased plasma kidney injury molecule-1 suggests early progressive renal decline in non-proteinuric patients with type 1 diabetes. Kidney Int, 89: 459-467, 2016

24. Ferreira JP, Verdonschot J, Collier T, Wang P, Pizard A, Bär C, Björkman J, Boccanelli A, Butler J, Clark A, Cleland JG, Delles C, Diez J, Girerd N, González A, Hazebroek M, Huby AC, Jukema W, Latini R, Leenders J, Levy D, Mebazaa A, Mischak H, Pinet F, Rossignol P, Sattar N, Sever P, Staessen JA, Thum T, Vodovar N, Zhang ZY, Heymans S, Zannad F: Proteomic Bioprofiles and Mechanistic Pathways of Progression to Heart Failure. Circ Heart Fail, 12: e005897, 2019

25. Beijer K, Nowak C, Sundström J, Ärnlöv J, Fall T, Lind L: In search of causal pathways in diabetes: a study using proteomics and genotyping data from a cross-sectional study. Diabetologia, 62: 1998-2006, 2019

26. Belmokhtar K, Ortillon J, Jaisson S, Massy ZA, Boulagnon Rombi C, Doue M, Maurice P, Fritz G, Gillery P, Schmidt AM, Rieu P, Toure F: Receptor for advanced glycation end products: a key molecule in the genesis of chronic kidney disease vascular calcification and a potential modulator of sodium phosphate co-transporter PIT-1 expression. Nephrol Dial Transplant, 34: 2018-2030, 2019

27. Kim JK, Park S, Lee MJ, Song YR, Han SH, Kim SG, Kang SW, Choi KH, Kim HJ, Yoo TH: Plasma levels of soluble receptor for advanced glycation end products (sRAGE) and proinflammatory ligand for RAGE (EN-RAGE) are associated with carotid atherosclerosis in patients with peritoneal dialysis. Atherosclerosis, 220: 208-214, 2012

28. Nakashima A, Carrero JJ, Qureshi AR, Miyamoto T, Anderstam B, Barany P, Heimburger O, Stenvinkel P, Lindholm B: Effect of circulating soluble receptor for advanced glycation end products (sRAGE) and the proinflammatory RAGE ligand (EN-RAGE, S100A12) on mortality in hemodialysis patients. Clin J Am Soc Nephrol, 5: 2213-2219, 2010

29. Shiotsu Y, Mori Y, Nishimura M, Sakoda C, Tokoro T, Hatta T, Maki N, lida K, Iwamoto N, Ono T, Matsuoka E, Kishimoto N, Tamagaki K, Matsubara H, Kosaki A: Plasma S100A12 level is associated with cardiovascular disease in hemodialysis patients. Clin J Am Soc Nephrol, 6: 718-723, 2011

30. Pratley RE, Baier L, Pan DA, Salbe AD, Storlien L, Ravussin E, Bogardus C: Effects of an Ala54Thr polymorphism in the intestinal fatty acid-binding protein on responses to dietary fat in humans. J Lipid Res, 41: 2002-2008, 2000

31. Abbas S, Raza ST, Chandra A, Rizvi S, Ahmed F, Eba A, Mahdi F: Association of ACE, FABP2 and GST genes polymorphism with essential hypertension risk among a North Indian population. Ann Hum Biol, 42: 461-469, 2015

32. Almaani SJ: Placental growth factor in pre-eclampsia: friend or foe? Kidney Int, 95: 730-732, 2019 
medRxiv preprint doi: https://doi.org/10.1101/2021.04.14.21255472; this version posted April 14, 2021. The copyright holder for this preprint

(which was not certified by peer review) is the author/funder, who has granted medRxiv a license to display the preprint in perpetuity.

All rights reserved. No reuse allowed without permission.

33. Bramham K, Seed PT, Lightstone L, Nelson-Piercy C, Gill C, Webster P, Poston L, Chappell LC: Diagnostic and predictive biomarkers for pre-eclampsia in patients with established hypertension and chronic kidney disease. Kidney Int, 89: 874-885, 2016

34. Mansour SG, Zhang WR, Moledina DG, Coca SG, Jia Y, Thiessen-Philbrook H, McArthur E, Inoue K, Koyner JL, Shlipak MG, Wilson FP, Garg AX, Ishibe S, Parikh CR: The Association of Angiogenesis Markers With Acute Kidney Injury and Mortality After Cardiac Surgery. Am J Kidney Dis, 74: 36-46, 2019

35. Fan Y, Li X, Xiao W, Fu J, Harris RC, Lindenmeyer M, Cohen CD, Guillot N, Baron MH, Wang N, Lee K, He JC, Schlondorff D, Chuang PY: BAMBI elimination enhances alternative TGF-beta signaling and glomerular dysfunction in diabetic mice. Diabetes, 64: 2220-2233, 2015

36. Guillot N, Kollins D, Gilbert V, Xavier S, Chen J, Gentle M, Reddy A, Bottinger E, Jiang R, Rastaldi MP, Corbelli A, Schlondorff D: BAMBI regulates angiogenesis and endothelial homeostasis through modulation of alternative TGFbeta signaling. PLoS One, 7: e39406, 2012

37. Lorz C, Benito-Martin A, Boucherot A, Ucero AC, Rastaldi MP, Henger A, Armelloni S, Santamaria B, Berthier CC, Kretzler M, Egido J, Ortiz A: The death ligand TRAIL in diabetic nephropathy. J Am Soc Nephrol, 19: 904-914, 2008

38. Stokman G, Stroo I, Claessen N, Teske GJ, Weening JJ, Leemans JC, Florquin S: Stem cell factor expression after renal ischemia promotes tubular epithelial survival. PLoS One, 5: e14386, 2010

39. Lutz M, Rosenberg M, Kiessling F, Eckstein V, Heger T, Krebs J, Ho AD, Katus HA, Frey $\mathrm{N}$ : Local injection of stem cell factor (SCF) improves myocardial homing of systemically delivered c-kit + bone marrow-derived stem cells. Cardiovasc Res, 77: 143-150, 2008

40. Bjorkbacka H, Yao Mattisson I, Wigren M, Melander O, Fredrikson GN, Bengtsson E, Goncalves I, Almgren P, Lagerstedt JO, Orho-Melander M, Engstrom G, Nilsson J: Plasma stem cell factor levels are associated with risk of cardiovascular disease and death. J Intern Med, 282: 508-521, 2017

41. van den Born BJ, van der Hoeven NV, Groot E, Lenting PJ, Meijers JC, Levi M, van Montfrans GA: Association between thrombotic microangiopathy and reduced ADAMTS13 activity in malignant hypertension. Hypertension, 51: 862-866, 2008 
medRxiv preprint doi: https://doi.org/10.1101/2021.04.14.21255472; this version posted April 14, 2021. The copyright holder for this preprint (which was not certified by peer review) is the author/funder, who has granted medRxiv a license to display the preprint in perpetuity.

All rights reserved. No reuse allowed without permission.

Table 1. Baseline characteristics of the study cohort.

\begin{tabular}{|c|c|}
\hline Baseline characteristics & $n=549$ \\
\hline \multicolumn{2}{|l|}{ Clinical Characteristics } \\
\hline Age, years & $51.6 \pm 16.7$ \\
\hline Female & $288(52.5)$ \\
\hline \multicolumn{2}{|l|}{ Race } \\
\hline Black & $105(19.1)$ \\
\hline White & $347(63.2)$ \\
\hline Other & $97(17.7)$ \\
\hline $\mathrm{eGFR}, \mathrm{ml} / \mathrm{min} / 1.73 \mathrm{~m}^{2}$ & $57.8 \pm 36.4$ \\
\hline \multicolumn{2}{|l|}{ CKD stage } \\
\hline Stage $1\left(\mathrm{eGFR}>90 \mathrm{ml} / \mathrm{min} / 1.73 \mathrm{~m}^{2}\right)$ & $132(24.0)$ \\
\hline Stage $2\left(\mathrm{eGFR} 60-89 \mathrm{ml} / \mathrm{min} / 1.73 \mathrm{~m}^{2}\right)$ & $92(16.8)$ \\
\hline Stage 3A (eGFR $\left.45-59 \mathrm{ml} / \mathrm{min} / 1.73 \mathrm{~m}^{2}\right)$ & $81(14.8)$ \\
\hline Stage 3B (eGFR $\left.30-44 \mathrm{ml} / \mathrm{min} / 1.73 \mathrm{~m}^{2}\right)$ & $91(16.6)$ \\
\hline Stage $4\left(\mathrm{eGFR} 15-29 \mathrm{ml} / \mathrm{min} / 1.73 \mathrm{~m}^{2}\right)$ & $101(18.4)$ \\
\hline Stage $5\left(\mathrm{eGFR}<15 \mathrm{ml} / \mathrm{min} / 1.73 \mathrm{~m}^{2}\right)$ & $52(9.5)$ \\
\hline Proteinuria, g/g creatinine & $1.7[0.4,3.8]$ \\
\hline \multicolumn{2}{|l|}{ Reason for Biopsy* } \\
\hline Proteinuria & $312(56.8)$ \\
\hline Hematuria & $134(24.4)$ \\
\hline Nephrotic Syndrome & $69(12.6)$ \\
\hline Nephritic Syndrome & $14(2.6)$ \\
\hline Abnormal eGFR/Other & $336(61.2)$ \\
\hline \multicolumn{2}{|l|}{ Primary Clinicopathologic Diagnosis } \\
\hline Proliferative glomerulonephritis & $162(29.5)$ \\
\hline Non-proliferative glomerulopathy & $96(17.5)$ \\
\hline Diabetic nephropathy & $64(11.7)$ \\
\hline Advanced glomerulosclerosis & $62(11.3)$ \\
\hline Vascular disease & $52(9.5)$ \\
\hline Tubulointerstitial disease & $47(8.6)$ \\
\hline Paraprotein-related disease & $35(6.4)$ \\
\hline Other & $31(5.6)$ \\
\hline \multicolumn{2}{|l|}{ Co-morbid Conditions } \\
\hline Diabetes Mellitus & $122(22.2)$ \\
\hline Hypertension & $287(52.3)$ \\
\hline Systemic Lupus Erythematosus & $90(16.4)$ \\
\hline Hepatitis C & $11(2.0)$ \\
\hline Hepatitis B & $4(0.7)$ \\
\hline HIV & $6(1.1)$ \\
\hline Malignancy & $80(14.6)$ \\
\hline \multicolumn{2}{|l|}{ Medications } \\
\hline ACEi/ARB & $257(46.8)$ \\
\hline MRA & $14(2.6)$ \\
\hline Calcium channel blockers & $137(25.0)$ \\
\hline Beta-blockers & $166(30.2)$ \\
\hline Immunosuppression & $102(18.6)$ \\
\hline Corticosteroids & $123(22.4)$ \\
\hline
\end{tabular}


medRxiv preprint doi: https://doi.org/10.1101/2021.04.14.21255472; this version posted April 14, 2021. The copyright holder for this preprint (which was not certified by peer review) is the author/funder, who has granted medRxiv a license to display the preprint in perpetuity.

All rights reserved. No reuse allowed without permission.

\begin{tabular}{|l|c|}
\hline Clinical site & \\
\hline Site 1 & $384(69.9)$ \\
\hline Site 2 & $104(18.9)$ \\
\hline Site 3 & $61(11.1)$ \\
\hline Clinical endpoints & \\
\hline$\geq 40 \%$ eGFR decline or ESKD & $170(31.4)$ \\
\hline Death & $82(15.0)$ \\
\hline
\end{tabular}

Data presented as mean \pm standard deviation, median [interquartile range], and count with frequencies $(\%)$ for binary and categorical variables

*Percentages do not add to 100 as there may have been more than 1 reason for a kidney biopsy SLE, Systemic Lupus Erythematosus; ACE, angiotensin converting enzyme inhibitor; ARB, angiotensin receptor blocker; MRA, mineralocorticoid receptor blocker; eGFR, estimated glomerular filtration rate; ESKD, end-stage kidney disease 
medRxiv preprint doi: https://doi.org/10.1101/2021.04.14.21255472; this version posted April 14, 2021. The copyright holder for this preprint (which was not certified by peer review) is the author/funder, who has granted medRxiv a license to display the preprint in perpetuity.

All rights reserved. No reuse allowed without permission.

Table 2. Top-ranked pathways for plasma biomarkers associated with adverse clinical outcomes.

\begin{tabular}{|c|c|c|c|c|}
\hline \multicolumn{5}{|c|}{ Top-ranked pathways for kidney disease progression } \\
\hline Rank & Biomarkers & Pathway* & p-value & FDR \\
\hline 1 & IL-10RB, CSF-1, IL16 & Other Interleukin Signaling & $3.99 \mathrm{e}-05$ & 0.007 \\
\hline 2 & TF, TM, PAR-1 & $\begin{array}{l}\text { Formation of Fibrin Clot (Clotting } \\
\text { Cascade) }\end{array}$ & $1.67 \mathrm{e}-04$ & 0.007 \\
\hline 3 & $\begin{array}{l}\text { TNFRSF9, VEGF-A, FGF-23, IL- } \\
\text { 4RA, IL-10RB, CD40, CSF-1, IL16, } \\
\text { TNFRSF11A, IL-15RA }\end{array}$ & $\begin{array}{l}\text { Cytokine Signaling in Immune } \\
\text { system }\end{array}$ & $1.78 \mathrm{e}-04$ & 0.007 \\
\hline 4 & TRAIL-R2, TNFRSF10A & TRAIL signaling & $2.25 \mathrm{e}-04$ & 0.007 \\
\hline 5 & VEGF-A, PGF & VEGF ligand-receptor interactions & $2.25 \mathrm{e}-04$ & 0.007 \\
\hline \multicolumn{5}{|c|}{ Top-ranked pathways for death } \\
\hline Rank & Biomarkers & Pathway* & p-value & FDR \\
\hline 1 & $\begin{array}{l}\text { CD40-L, IL-4RA, CD4, IL-18R1, } \\
\text { IL6, SCF, IL-15RA, IL-27, Gal-9, IL- } \\
\text { 8, TNFRSF11A, OPG }\end{array}$ & $\begin{array}{l}\text { Cytokine Signaling in Immune } \\
\text { system }\end{array}$ & $2.04 \mathrm{e}-05$ & 0.004 \\
\hline 2 & $\begin{array}{l}\text { IL-27, IL-4RA, CD4, Gal-9, IL-18R1, } \\
\text { IL-8, IL6, IL-15RA }\end{array}$ & Signaling by Interleukins & $5.77 \mathrm{e}-05$ & 0.006 \\
\hline 3 & TRAIL-R2, TNFRSF10A & TRAIL signaling & $2.88 \mathrm{e}-04$ & 0.017 \\
\hline 4 & CTSL1, ACE2 & Attachment and Entry & $4.48 \mathrm{e}-04$ & 0.017 \\
\hline 5 & TRAIL-R2, TNFRSF10A & Regulation by c-FLIP & $5.40 \mathrm{e}-04$ & 0.017 \\
\hline
\end{tabular}

Biomarkers associated with kidney disease and progression and death (Figure 2, Supplemental Table 4 and 5) were submitted to Reactome for pathway analyses. *Listed are the top five ranked pathways. TRAIL, TNF-related apoptosis-inducing ligand; VEGF, vascular endothelial growth factor; c-FLIP, FADD-like IL-1 $\beta$-converting enzyme-inhibitory protein. Name and abbreviation of each biomarker are shown in Supplemental Table 5. 


\section{Figure Legends}

Figure 1. Circulating plasma proteins associated with histopathologic lesions in native kidney biopsy specimens.

The heatmap shows associations between histopathologic lesions and biomarkers after Bonferroni correction. Beta coefficients are derived from multivariable linear regression models, adjusted for age, sex, race, and eGFR and displayed as colors ranging from blue to red. Reference is absence of lesion for glomerular inflammation and inflammation in the non-fibrosed interstitium; none/mild lesion severity for mesangial expansion, acute tubular injury, and arteriolar sclerosis; and 0-25\% of cortical volume affected for global glomerulosclerosis, inflammation in the fibrosed interstitium, and interstitial fibrosis/tubular atrophy.

Figure 2. Circulating plasma proteins associated with kidney disease progression (A) and death (B).

Results are derived from proportional hazards models adjusted for eGFR, race, age, sex, $\log$ (proteinuria), and primary clinicopathologic diagnosis. Horizontal dotted lines show Bonferroni-adjusted significance thresholds and vertical dotted lines mark the hazard ratio of 1. Name and abbreviation of each biomarker are shown in Supplemental Table 5. KD, kidney disease. 


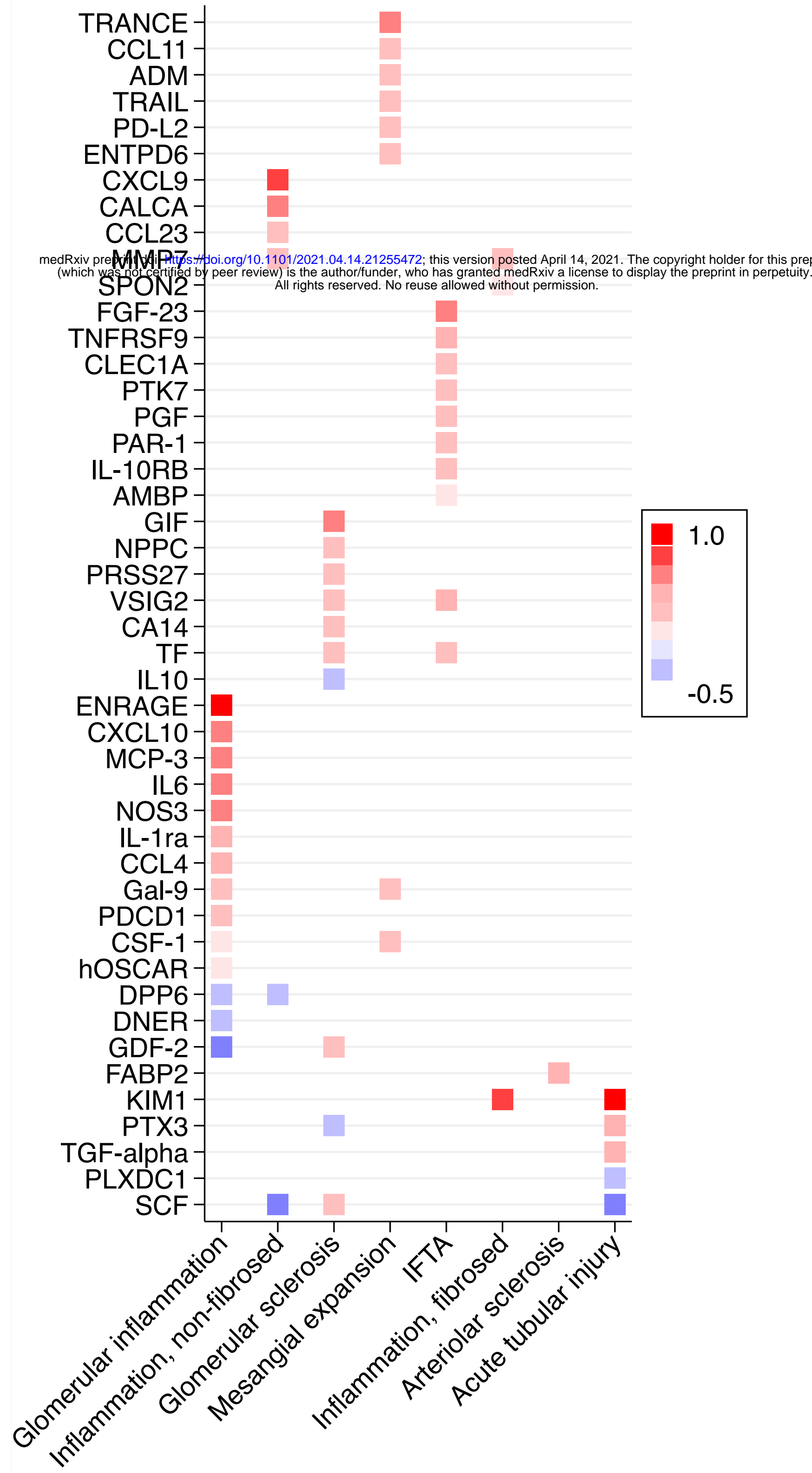




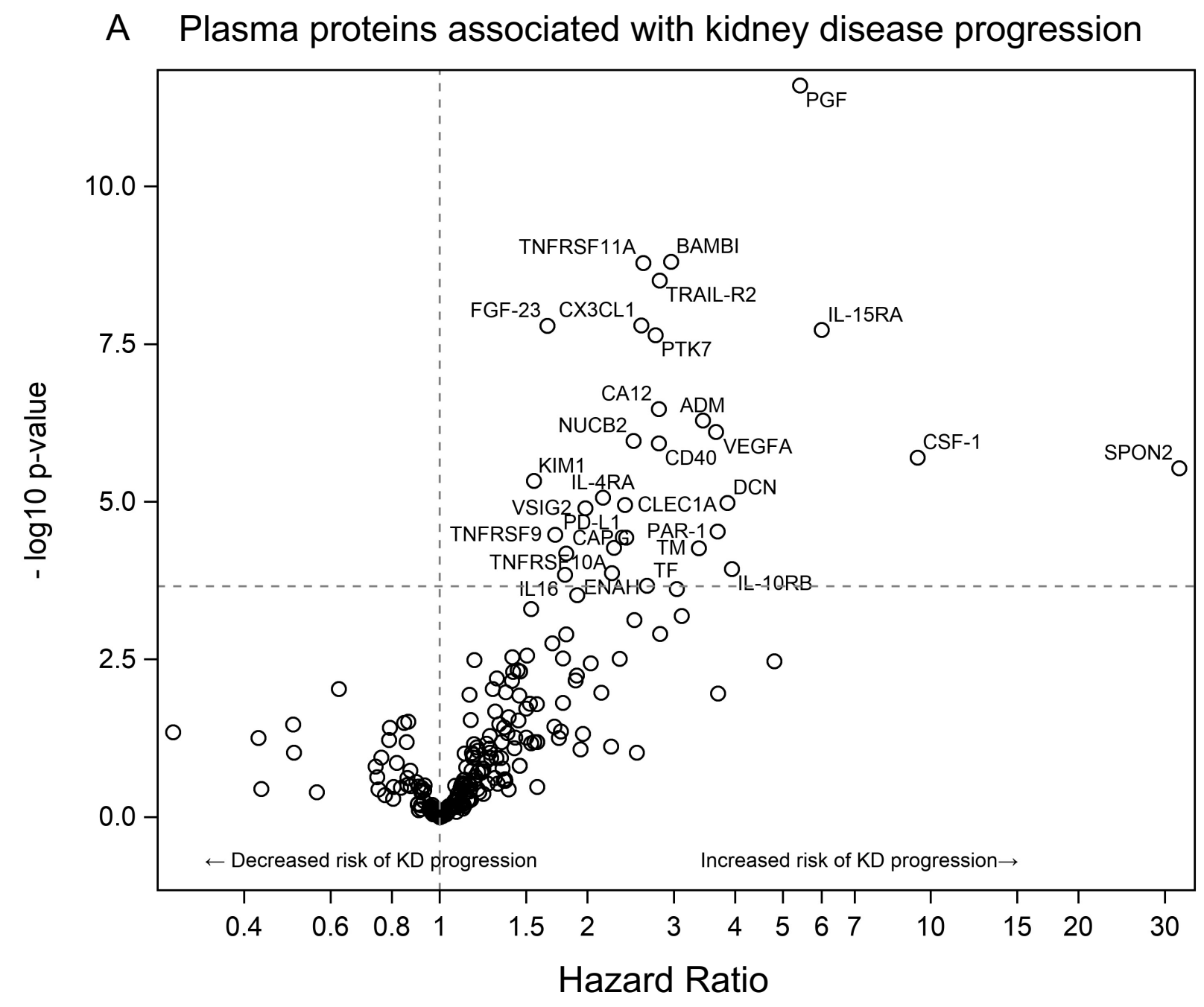

Plasma proteins associated with death

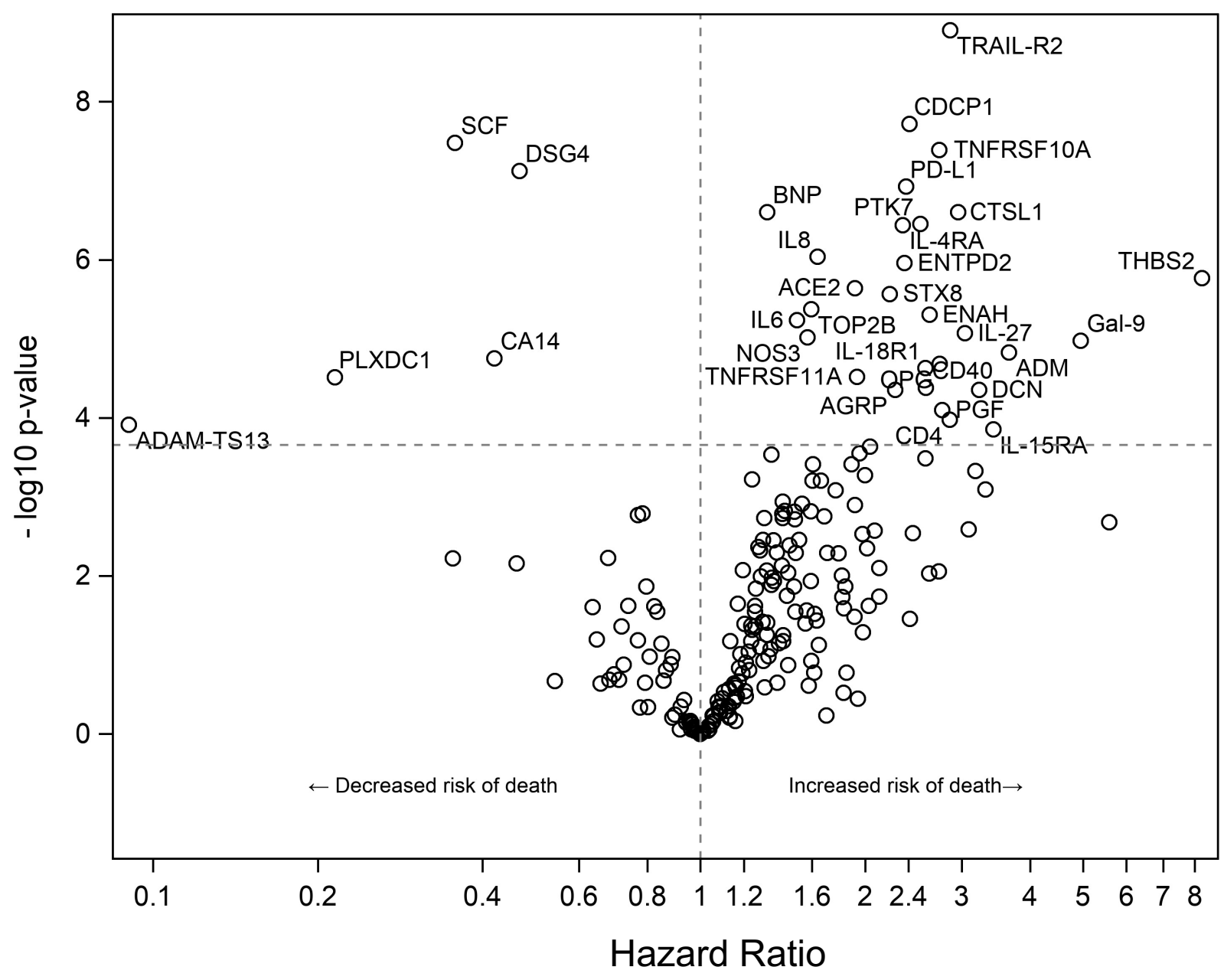

